\title{
MANAGEMENT AND ADMINISTRATION OF GOODS PROMOTION IN THE ORGANIZATION
}

\section{УПРАВЛІННЯ ТА КЕРУВАННЯ ПРОСУВАННЯМ ТОВАРІВ НА ПІДПРИЄМСТВІ}

\section{UDC 658.8}

https://doi.org/10.32843/infrastruct37-45

\author{
Lukash Svitlana \\ Candidate of Economic Sciences \\ Sumy National Agrarian University \\ Falana Taoreed Debo \\ Student \\ Sumy National Agrarian University
}

\begin{abstract}
The article discussed positioning strategies, as a process of creating a market image of a product based on its unique characteristics, combination of methods, forms and approaches to the implementation of the philosophical concept of the functioning of any business. The effectiveness of positioning depends on the synergy and relevance of the current period of the system of strategic priorities chosen by the enterprise. The basis of strategy development is adaptation to the conditions of the competitive environment, since the potential marginal profit of the enterprise to a large extent depends on the structure of the industry, in other words, on the combined effect of the five main factors of industry competition: threats of new firms entering the industry; the ability of suppliers to overestimate resource prices; the ability of buyers to push the level of prices of products in the industry; the intensity of competition between existing manufacturers in the industry.

Key words: products, promotion, marketing mix, management, administration.
\end{abstract}

В статье рассмотрены стратегии позиционирования, как процесс создания рыночного образа товара на основе его уникальных характеристик. Эфрфективность позиционирования зависит от синергии и актуальности текущего периода системы стратегических приоритетов, выбранной предприятием. Основой разработки стратегии является адаптация к условиям конкурентной среды, поскольку потенциальный предельный доход предприятия в значительной степени зависит от структуры отрасли, иными словами, от комбинированного воздействия пяти основных фракторов области конкуренция: угрозы вхождения в отрасль новых форм; способность поставщиков завышать чены на ресурсы; интенсивность конкуренции между существующими производителями в отрасли. Применение стратегии с наименьшими затратами требует от предприятий развивать собственную стратегическую компетенцию для совершенствования производства, делать значительные предварительные инвестиции в приобретение сельскохозяйственной техники, оборудования, технологий и т.д.

Ключевые слова: продукты, продвижение, маркетинговый микс, менеджмент, администрация.

Сучасні умови ффункціонування вітчизняних підприємств значно ускладнюються низкою багатовимірних перетворень, що відбуваються в суспільстві, зокрема прискоренням глобалізації економічних процесів, підвищенням невизначеності та нестабільності зовнішнього середовища, посиленням конкуренції на внутрішньому та зовнішньому ринках, зміною соціально-економічні відносини тощо. Ці проблеми особливо торкнулися сільськогосподарських підприємств. В даний час все більш і більш успішні підприємства пов'язують ефрективність своєї діяльності з використанням маркетингових концепцій, суть яких суттєво змінилася з розвитком та транссрормацією ринкових відносин. У статті розглянуто стратегію позиціонування, як процес створення ринкового образу товару на основі його унікальних характеристик, $\epsilon$ поєднанням методів, форм і підходів до реалізації філососьської концепції фуннкціонування будь-якого бізнесу, в тому числі аграрного. Ефрективність позиціонування залежить від синергії та актуальності поточного періоду системи стратегічних пріоритетів, обраної підприємством. Стратегіі позиціонування є невід'ємною частиною маркетингових програм, з розвитком інформаційних технологій їх роль та значення у формуванні стратегічного набору підприємств постійно зростають. Основою розробки стратегії $\epsilon$ адаптація до умов конкурентного середовища, оскільки потенційний граничний прибуток підприємства значною мірою залежить від структури галузі, іншими словами, від комбінованого впливу п'яти основних фракторів галузі конкуренція: загрози входження у галузь нових фрірм; здатність постачальників завищувати ціни на ресурси; здатність покупців підштовхувати рівень цін на продукцію в галузі; загрози появи на ринку конкурентоспроможної продукціїзамінника; інтенсивність конкуренції між існуючими виробниками в галузі. Застосування стратегії з найменшими витратами вимагає від підприємств розвивати власну стратегічну компетенцію для вдосконалення виробництва, робити значні попередні інвестиції у придбання сільськогосподарської техніки, обладнання, технологій, здобуття значної частки на ринку тощо.

Ключові слова: продукти, просування, маркетинговий мікс, менеджмент, адміністрація.

Formulation of the problem. Modern conditions of functioning of domestic enterprises are significantly complicated by a number of multidimensional transformations taking place in society, in particular by accelerating the globalization of economic processes, increasing uncertainty and instability of the external environment, increasing competition on the domestic and foreign markets, changing socio-economic relations, etc. These problems have particularly affected agricultural enterprises.

Nowadays more and more successful enterprises associate the effectiveness of their activities with the use of marketing concepts, the essence of which has changed significantly with the development and transformation of market relations. The enterprise strategy is a system of hierarchically constructed conceptual priorities for managing operations at all levels of management.
Analysis of recent research and publications. Significant scientific achievements in the theory of product promotion on the market belong to such scientists as Ambler T. [5], Armstrong G., Kotler F. [6], Voichak A. [8], Dichtl E., HershgenX., Doyle P. [7], Saunders D., Lamburn J., Chumpitas R., Schuling I. and others. Despite a comprehensive study of the problems of promoting the production of the enterprise, the features of promotion of agricultural products remain insufficiently covered.

Problem statement. The purpose of this study is to study the theoretical and methodological foundations of managing the promotion of enterprise products and to develop practical recommendations for improving the efficiency of promotion of agricultural products.

Main material. Ukraine is gradually becoming a full player in the global market (fig. 1-3). Ukraine has been the world leader in the production and 
export of sunflower oil for several consecutive years. The remaining key positions are occupied by cereals (corn, wheat, barley), as well as oilseeds. The main importers of Ukrainian agricultural products in 2018 are Asian countries (44.6\%) and the European Union (33\%). North African countries ranked third with $12.3 \%$. Accordingly, agribusiness, the farmers of Ukraine are in the conditions of the highest competition. To survive in such competition and to be successful the farmer must always be one step ahead of hos/her competitors.

In modern conditions, the positioning of agrarian enterprises is a competitive low cost strategy, i.e. a strategy of low prices (strategy of penetration into the market, strategy of price breakthrough). Price positioning is the most flexible and changing element in the system of strategic priorities of the enterprise. For agricultural enterprises, this factor is an indication of the timely and correct incorporation of the market situation, which in the short term creates conditions for survival or maximization of their profit, the maintenance of a certain share in the market, etc. In addition, the purpose of strategic price positioning is to secure consumer value in the minds of the consumers, rather than to reimburse the costs of the manufacturer. Effective price positioning plays a sig-

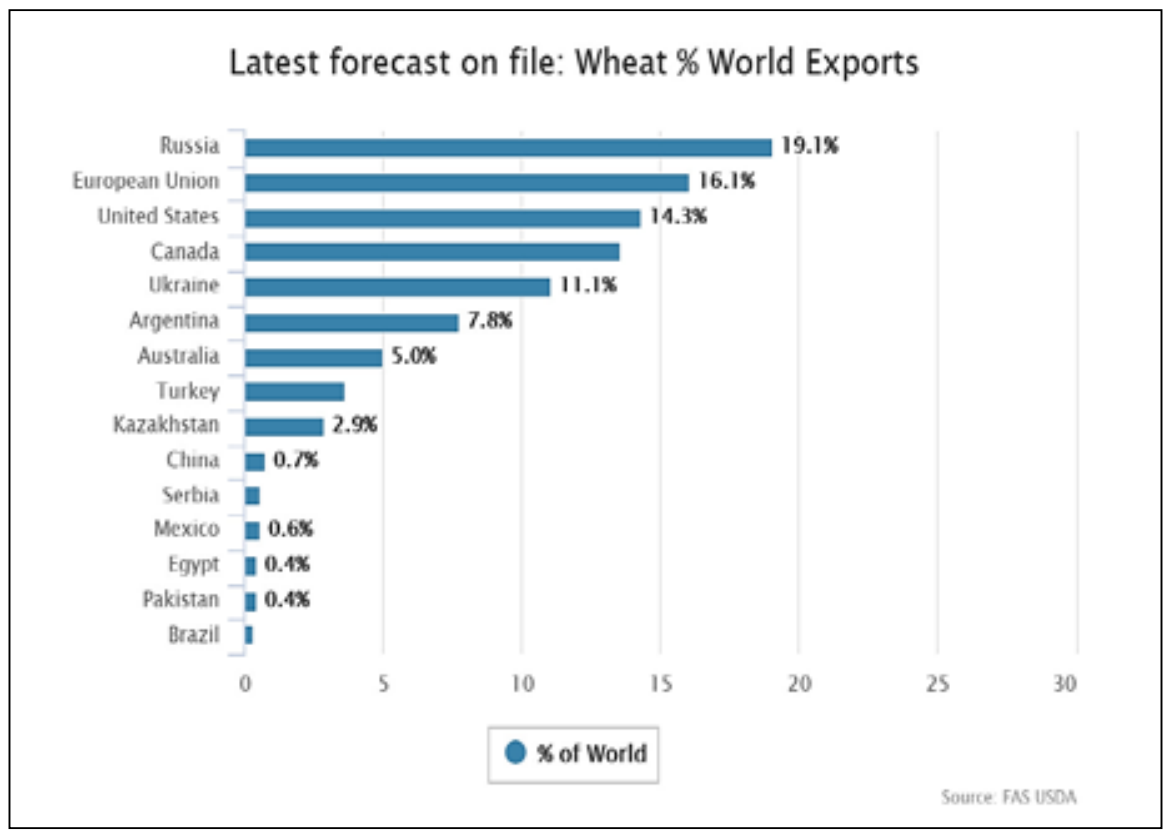

Fig. 1. Wheat world export, 2018

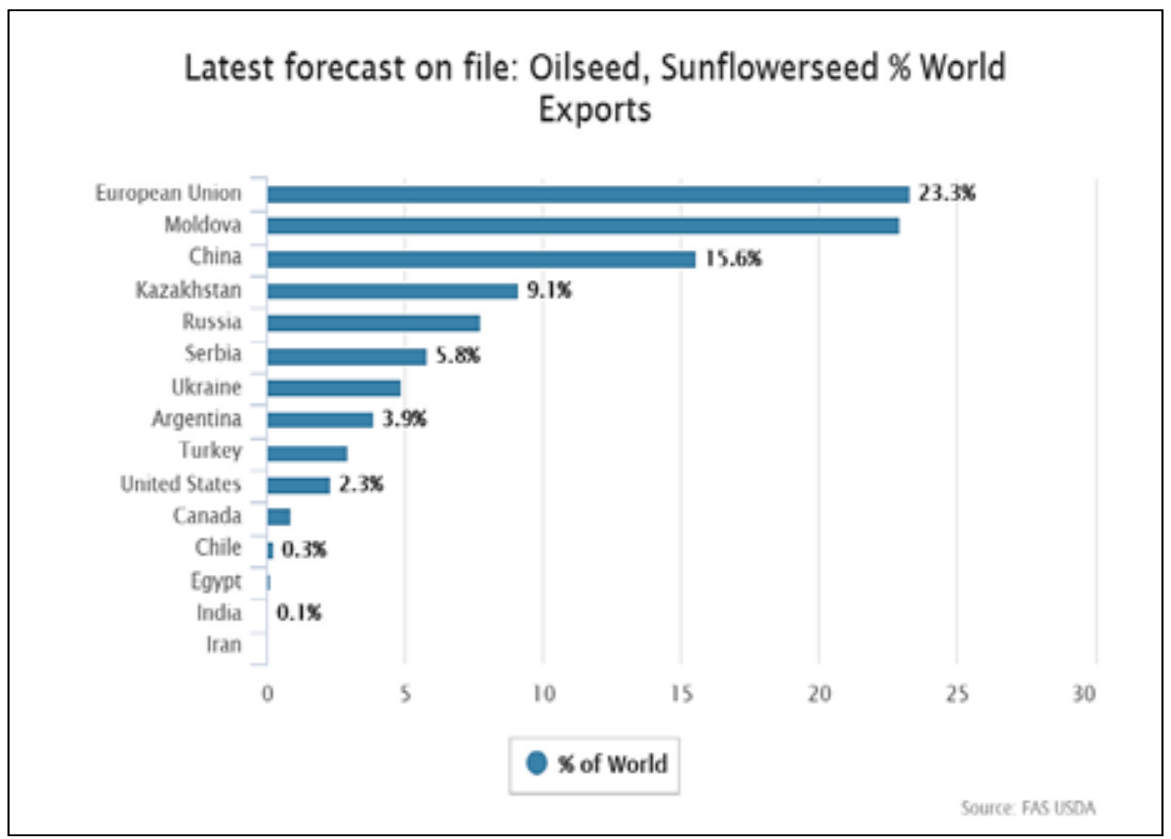

Fig. 2. Sunflower world export, 2018 


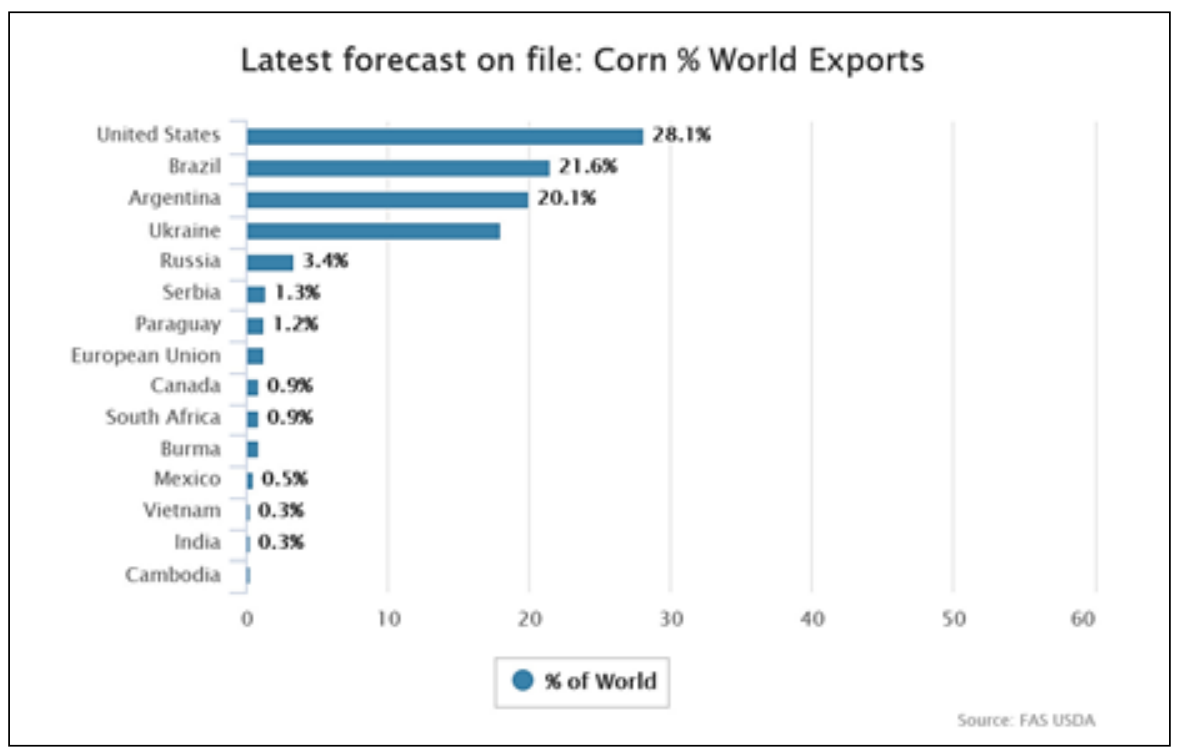

Fig. 3. Corn world export, 2018

nificant role in the administrative management of the enterprise.

On the other hand, if agricultural producers offer products that are similar from a marketing point of view, the conditions of competition (both in domestic and foreign markets) will depend on the market power of each player. In this case, it will be a typical strategy to follow a powerful market leader, which will turn into price discounts for farmers and the need for their state support.

In our opinion, such a concept of development is more acceptable, which envisages the possibility of using the best of experience, but offering on the market qualitatively different, differentiated products. Rational differentiation of agrarian enterprises' products will not only better meet demand and partially solve the problem of the loss-making nature of production of certain types of agricultural products, but will also protect the domestic market from the low quality of imported substitutes. Under this condition, we can state the potential of the domestic agrarian sector to achieve sustainable competitive advantage in the long run.

To relate the customer's definition of value to the agribusiness firm's product strategy, it is helpful to visualize the firm's product offering as consisting of four distinct, but highly interrelated, parts. This way of looking at the value bundle has been called the total product concept. The total product concept is a means to relate the customers' definition of value to the agribusiness firm's product strategy by visualizing the four parts of the firm's product offering: the generic product, the expected product, the value added product, and the potential product (Fig.4). Understanding these different levels can help an agribusiness marketer better understand how value is added, and ultimately, can guide development of the product and promotion strategies.

The foundation for a firm's product offering is the generic product. This is the standard product with no special services or features attached.

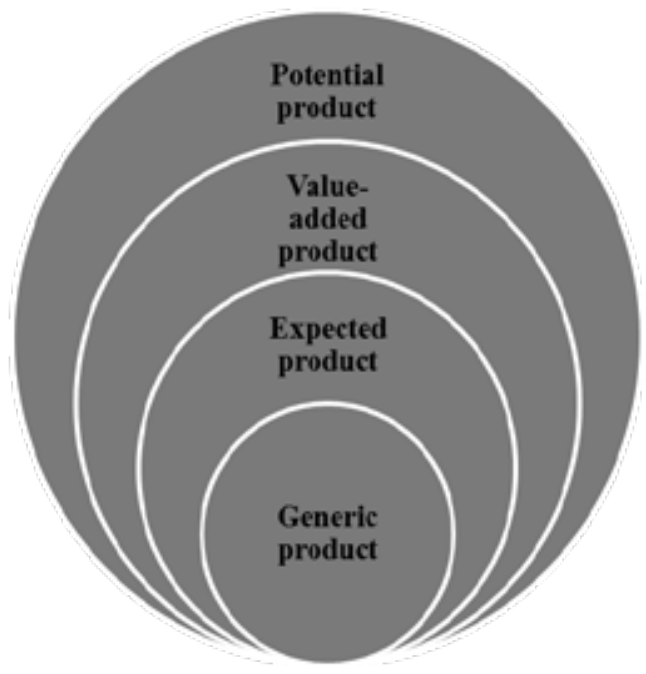

Fig. 4. The total product concept

The quality of agricultural products, its ecological compatibility, the refusal to use chemical stimulators of plant and animal growth can become competitive advantages in the consolidation of agribusiness products in Ukraine. The conceptual difference between the domestic agrarian sector may be the use of less intensive but socially significant technologies: not harmful to the environment; those that require less government support, etc.

The purpose of promotion is both to communicate with buyers and to influence on them. Effective promotion requires an understanding of the process of persuasion and how this process is affected by 
environmental factors. The potential buyer must not only receive the desired information but should also be able to comprehend that information. Information must be sufficiently powerful to motivate this buyer to react positively.

Today, with the increased use of digital technology, Internet marketing and promotion are becoming more and more relevant. Their great advantage is that consumers are actively using the Internet, such tools contribute to transparency and cause positive emotions, as well as relatively low costs.

One of alternative for agrarian enterprises nowadays is creating an Agrarian cooperative, the main goal of it is to enable existing and potential managers of agricultural cooperatives to identify and address major challenges that are specific to cooperatives in market-oriented agricultural development. One of the objectives of $\mathrm{Ag}$ cooperative is to promote agricultural products on internal and external markets.

Positioning strategies, as a process of creating a market image of a product based on its unique characteristics, is a combination of methods, forms and approaches to the implementation of the philosophical concept of the functioning of any business, including the agrarian one. The effectiveness of positioning depends on the synergy and relevance of the current period of the system of strategic priorities chosen by the enterprise. Positioning strategies are an integral part of marketing programs, with the development of information technology, their role and importance in shaping the strategic set of enterprises is steadily increasing. One of the most well-known developers of the concept of positioning M. Porter believes that the basis of strategy development is adaptation to the conditions of the competitive environment, since the potential marginal profit of the enterprise to a large extent depends on the structure of the industry, in other words, on the combined effect of the five main factors of industry competition: threats of entering the industry of new firms; the ability of suppliers to overestimate resource prices; the ability of buyers to push the level of prices of products in the industry; threats of appearance on the market of competitive substitute products; the intensity of competition between existing manufacturers in the industry.

Promotional goals include many different tools including creating awareness, getting consumers to try products, providing information, retaining loyal customers, increasing the use of products, and identifying potential customers, as well as teaching potential service clients what is needed to "co-create" the services provided. Any promotional campaign may seek to achieve one or more of these goals:

Creating awareness: Consumers are committed to healthier lifestyles and make their dairy purchases based on perceptions of health, primarily around "all natural," organic, and low-sugar options. Promotion through ads on social media platforms and local radio

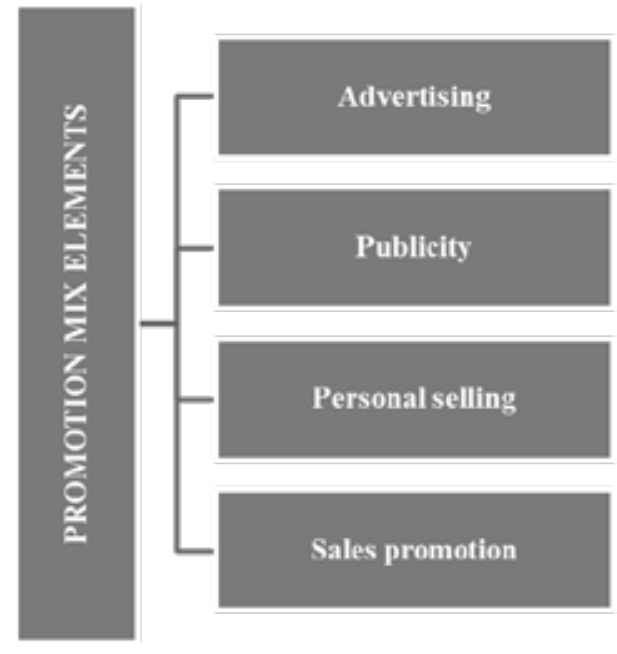

Fig. 5. Promotion mix elements

or television, coupons in local papers, flyers, and so forth can create awareness of a new business or product. Large companies often use catchy slogans to build brand awareness. Over a third of consumers report of eating more healthy food. In addition, some of the most common reasons influencing consumer purchasing decisions are related to health. This finding suggests that perceptions of a category's healthiness are becoming increasingly important. Some attributes are more likely to influence whether the consumer views product as healthy. For example, consumers prefer slogans "low sugar", "natural", "organic" and non-GMO product.

Getting consumers to try products: Promotion is almost always used to get people to try a new product or to get nonusers to try an existing product. Sometimes free samples are given away. Consumers are eager to try new dairy brands and products. Many are willing to purchase from new dairy brands in addition to their existing brands. While consumers' openness to trying new brands and products creates opportunities, successful brands must also be conscious of the challenges of sustaining new success. Brands must constantly monitor and adapt to consumers' shifting tastes to meet the needs of the dairy consumer and stay ahead of competition.

Providing information: Most of consumers want to know more about ingredients, sourcing, and manufacturing processes when they are considering purchases. Informative promotion is more common in the early stages of the product life cycle. An informative promotion may explain what ingredients will do for a consumer's health, describe why the product is better, inform the customer of a new low price, or explain where the item may be purchased.

People typically prefer to know origin of the ingredients and whether they are sourced in a sustainable, environmentally friendly way. Thus, an informative advertising may stimulate interest in a product. Consumer watchdogs and social critics applaud the infor- 
mative function of promotion because it helps consumers to make decisions.

Increasing the amount and frequency of use: Promotion is often used to get people to use more of a product and to use it more often. The National Cattlemen's Beef Association reminds Americans to "Eat More Beef." The most popular promotion to increase the use of a product may be frequent-flyer or -user programs. The Marriott Rewards program awards points for each dollar spent at a Marriott property. At the Platinum level, members receive a guaranteed room, an upgrade to the property's finest available accommodations, access to the concierge lounge, a free breakfast, free local phone calls, and a variety of other goodies.

Identifying target customers: Promotion helps find customers. One way to do this is to list a website as part of the promotion.

Channel and value preferences vary by age. Millennials perceive value in premium products and prefer purchasing online, while Generation $X$ and baby boomers perceive more value from private label and discount channels. Consumers in different age groups have distinct differences in how they purchase products and its very often used in management of goods promotion.

Teaching the customer: For service products, it is often imperative to actually teach the potential client the reasons for certain parts of a service.

The promotion strategy is the most visible marketing strategy, designed to get the attention of prospective customers and convince them to buy from you. Promotion strategy includes such stages:

- the composition of promotion strategy;

- developing a promotion strategy;

- communications objectives;

- deciding the role of the promotion components;

- determining the promotion budget;

- promotion component strategies;

- integrating and implementing the promotion strategy;

- effectiveness of promotion strategy.

Conclusions. The agricultural market is perfectly competitive. The application of the least cost strategy requires enterprises to develop their own strategic competencies to improve production, make significant prior investments in acquiring agricultural machinery, equipment, technologies, gaining a signif- icant share in the market, etc. Agricultural enterprises should have sufficient flexibility to respond promptly to competitors' actions and changes in the market environment, to constantly conduct market research to compare their own performance with leading players in the industry and in international markets.

Promotion is used by the business to raise awareness, persuade or remind consumers about their products, services, activities, and more. Product promotion in both domestic and international markets should be an integral part of enterprise marketing policy. For Ukraine, today there is a need to increase the efficiency of managing the promotion of goods to domestic and international markets, taking into account the peculiarities of their development. Effective promotion management is inextricably linked to planning and budgeting to take into account the trends of global promotion. To do this, the company needs to develop a strategy using the possible elements of promotion.

In our work, we considered an issue of management and administration of goods promotion in the organization. Analysing agricultural area faces certain analytical complexities. Challenges and problematic issues outline prospects for further researches management and administration of goods promotion in the organization.

\section{REFERENCES:}

1. Porter M. (1990) Competetive Advantage of Nations. N-Y. : Free Press.

2. Ries A., Trout J. (1986) Marketing Warfar. N-Y. : McGraw-Hill.

3. Ries A., Trout J. (1981) Positioning: The battle for your mind. N-Y. : McGraw-Hill.

4. Schultz M., Hatch M., Larsen M. (2000) The expressive organizations. N.-Y.: Oxford University Press, Inc.

5. Ambler T., Thorpe R., Holloway J (2008) Marketing and the Bottom Line: Assessing Marketing Performance. London: Performance Management. Palgrave Macmillan. DOI https://doi.org/10.1057/9780230288942_10

6. Kotler, P. and Armstrong, G. (2013) Principle of Marketing. 15th Edition, Prentice Hall.

7. Doyle, P., \& Stern, P. (2006). Marketing management and strategy (4th ed.). Upper Saddle River, NJ: Pearson.

8. Voichak A.V. (2007) Marketynghovyj menedzhment [Marketing Management]. Kyiv: A Tutorial, KNEU (in Ukrainian). 
Lukash Svitlana

Candidate of Economic Sciences

Sumy National Agrarian University

Falana Taoreed Debo

Student

Sumy National Agrarian University

\section{MANAGEMENT AND ADMINISTRATION OF GOODS PROMOTION IN THE ORGANIZATION}

Modern conditions of functioning of domestic enterprises are significantly complicated by a number of multidimensional transformations taking place in society, in particular by accelerating the globalization of economic processes, increasing uncertainty and instability of the external environment, increasing competition on the domestic and foreign markets, changing socio-economic relations, etc. These problems have particularly affected agricultural enterprises.

Nowadays more and more successful enterprises associate the effectiveness of their activities with the use of marketing concepts, the essence of which has changed significantly with the development and transformation of market relations. The enterprise strategy is a system of hierarchically constructed conceptual priorities for managing operations at all levels of management.

Significant scientific achievements in the theory of product promotion on the market belong to such scientists as Ambler T. [5], Armstrong G., Kotler F. [6], Voichak A. [8], Dichtl E., HershgenX., Doyle P. [7], Saunders D., Lamburn J., Chumpitas R., Schuling I. and others. Despite a comprehensive study of the problems of promoting the production of the enterprise, the features of promotion of agricultural products remain insufficiently covered.

The purpose of this study is to study the theoretical and methodological foundations of managing the promotion of enterprise products and to develop practical recommendations for improving the efficiency of promotion of agricultural products. In modern conditions, the positioning of agrarian enterprises is a competitive low cost strategy - a strategy of low prices (strategy of penetration into the market, strategy of price breakthrough). Price positioning is the most flexible and changing element in the system of strategic priorities of the enterprise. For agricultural enterprises, this factor is an indication of the timely and correct incorporation of the market situation, which in the short term creates conditions for survival or maximization of their profit, the maintenance of a certain share in the market, etc. In addition, the purpose of strategic price positioning is to secure consumer value in the minds of the consumer, rather than to reimburse the costs of the manufacturer. Effective price positioning plays a significant role in the administrative management of the enterprise.

On the other hand, if agricultural producers offer products that are similar from a marketing point of view, the conditions of competition (both in domestic and foreign markets) will depend on the market power of each player. In this case, it will be a typical strategy to follow a powerful market leader, which will turn into price discounts for farmers and the need for their state support.

In our opinion, such a concept of development is more acceptable, which envisages the possibility of using the best of experience, but offering on the market qualitatively different, differentiated products. Rational differentiation of agrarian enterprises' products will not only better meet demand and partially solve the problem of the loss-making nature of production of certain types of agricultural products, but will also protect the domestic market from the low quality of imported substitutes. Under this condition, we can state the potential of the domestic agrarian sector to achieve sustainable competitive advantage in the long run.

The quality of agricultural products, its ecological compatibility, the refusal to use chemical stimulators of plant and animal growth can become competitive advantages in the consolidation of agribusiness products in Ukraine. The conceptual difference between the domestic agrarian sector may be the use of less intensive but socially significant technologies: not harmful to the environment; those that require less government support, etc.

Positioning strategies, as a process of creating a market image of a product based on its unique characteristics, is a combination of methods, forms and approaches to the implementation of the philosophical concept of the functioning of any business, including agrarian ones. The effectiveness of positioning depends on the synergy and relevance of the current period of the system of strategic priorities chosen by the enterprise. In our work, we considered an issue of management and administration of goods promotion in the organization. Analyzing agricultural area faces certain analytical complexities. Challenges and problematic issues outline prospects for further researches management and administration of goods promotion in the organization. 